\title{
Nematodes associated with Iguana iguana (Linnaeus, 1758) (Squamata, Iguanidae) in Semi-arid areas of Northeastern Brazil
}

\author{
D. A. Teles ${ }^{a}$, S. V. Brito ${ }^{b}$, A. A. M. Teixeira ${ }^{a}$, S. C. Ribeiro ${ }^{b}$, J. A. Araujo-Filho ${ }^{b}$, V. F. Lima ${ }^{b}$, \\ A. M. A. Pereira ${ }^{b}$ and W. O. Almeidac \\ aPrograma de Pós-graduação em Ciências Biológicas (Zoologia), Departamento de Sistemática e Ecologia - DSE, \\ Centro de Ciências Exatas e da Natureza - CCEN, Universidade Federal da Paraíba - UFPB, Cidade Universitária, \\ Campus I, CEP 58059-900, João Pessoa, PB, Brazil \\ bPrograma de Pós-graduação em Bioprospecção Molecular, Departamento de Química Biológica, Universidade \\ Regional do Cariri - URCA, Rua Cel. Antônio Luiz, 1161, Campus do Pimenta, CEP 63105-000, Crato, CE, Brazil \\ 'Departamento de Ciências Biológicas, Universidade Regional do Cariri - URCA, Rua Cel. Antônio Luiz, 1161, \\ Campus do Pimenta, CEP 63105-000, Crato, CE, Brazil \\ * e-mail: diegoateles@gmail.com
}

Received: October 27, 2015 - Accepted: March 23, 2016 - Distributed: August 31, 2017

(With 1 figures)

\begin{abstract}
Nematodes were analyzed in Iguana iguana, a large lizard Iguanidae that is widely distributed throughout the Americas. The aims of the study were investigate the helminths associated with the lizard, I. iguana in semi-arid areas of northeastern Brazil and analyze the parasitological indices (prevalence, and mean intensity of infection). A total of 18 specimens of I. iguana were examined ( 8 males and 10 females). The overall prevalence of infection was $66.6 \%$ $(12 / 18)$, while in males, it was $75 \%(6 / 8)$ and in females, $60 \%(6 / 10)$. Iguana iguana was identified as a new host for Physaloptera sp., Atractis sp., Piratuba sp. and Subulura sp. This registered contributes to the knowledge of helminth diversity associated with this host.
\end{abstract}

Keywords: helminths, Green Iguana, parasitism, Caatinga domain.

\section{Nematoda associados a Iguana iguana (Linnaeus, 1758) (Squamata: Iguanidae) em áreas do semi-árido do nordeste do Brasil}

\section{Resumo}

Foram analisados os nematóides em Iguana iguana, um grande lagarto Iguanidae que possui ampla distribuição pelas Américas. Os objetivos do estudo foram investigar os helmintos associados ao lagarto I. iguana e seus índices parasitológicos (prevalência e intensidade média de infecção). Foram examinados 18 espécimes (oito machos e 10 fêmeas). A prevalência total foi de 66,6\% (12/18), nos machos foi de 75\% (6/8) e nas fêmeas 60\% (6/10). Iguana iguana foi identificado como um novo hospedeiro para Physaloptera sp., Atractis sp., Piratuba sp., e Subulura sp. Este registro contribui para o conhecimento da diversidade de helmintos associados a este hospedeiro.

Palavras-chave: helmintos, Iguana Verde, parasitismo, domínio de Caatinga.

\section{Introduction}

Iguana iguana (Linnaeus, 1758) occurs in regions of North America (Mexico), Central America (Panama, Nicaragua, Guatemala and Costa Rica), South America (Brazil, Peru, Venezuela) (Lara-López and González-Romero, 2002; Arrojo, 2002), and some Caribbean islands, such as Cozumel, Utila and Roatan (Arce-Nazario and Carlo, 2012). There are introduced populations in the United States, in Florida and Hawaii (Connant and Collins, 1998; Smith et al., 2007), Puerto Rico (López-Torrez et al., 2012),
Dominican Republic (Pasachnik et al., 2012), and Antilles (Powell et al., 2011).

Iguana iguana includes heliothermal arboreal lizards of diurnal activity that grow to a large size in adulthood, up to about $1.80 \mathrm{~m}$ total length. The females of this species nest close to rivers, streams, and other bodies of water, where the nest generally contains 14 eggs (Campos, 2004). They often use vegetation microhabitats close to bodies of water. Their diet essentially consists of plant material, 
mainly leaves, thus they are considered a polyspecific herbivore (Lara-López and González-Romero, 2002).

Parasitological investigations into these iguanids have shown that they host a diverse group of parasites, including nematodes (Breves et al., 2011; Lopes et al., 2006; Sarmiento et al., 1999; Freitas and Lent, 1937; Dyer et al., 1999), trematodes (Ávila and Silva, 2011; Freitas and Lent, 1937), cestodes (Ávila and Silva, 2010), and mites and ticks (Dantas-Torres et al., 2008).

The aims of the study were to investigate the helminths associated with I. iguana in semi-arid areas of the Brazil and the parasitological indices (prevalence and mean intensity) of the infections.

\section{Materials and Methods}

Eighteen specimens of I. iguana were analyzed (eight males and 10 females). The hosts were obtained from the Herpetological Collection of the Regional University of
Cariri (URCA-H) under the following numbers: 5535-5537, 6736-6737, and 9474-9486. Specimens of I. iguana came from seven different municipalities of northeast Brazil: $\operatorname{Exu}(\mathrm{N}=7)\left(07^{\circ} 30^{\prime} \mathrm{S}, 39^{\circ} 43^{\prime} \mathrm{W}\right)$ and Moreilândia $(\mathrm{N}=1)$ $\left(07^{\circ} 38^{\prime} \mathrm{S}, 39^{\circ} 33^{\prime} \mathrm{W}\right)$ in the state of Pernambuco and Aiuaba $(\mathrm{N}=3)\left(06^{\circ} 34^{\prime} \mathrm{S} 40^{\circ} 07^{\prime} \mathrm{W}\right)$, Barro $(\mathrm{N}=1)\left(07^{\circ} 10^{\prime} \mathrm{S}\right.$, $\left.38^{\circ} 46^{\prime} \mathrm{W}\right)$, Crato ( $\left.=1\right)\left(07^{\circ} 14^{\prime} 02^{\prime}\right.$ ' S 39 24'32” O), Juazeiro do Norte $(\mathrm{N}=1)\left(07^{\circ} 12^{\prime} \mathrm{S}, 39^{\circ} 18^{\prime} \mathrm{W}\right)$ and Santana do Cariri $(\mathrm{N}=4)\left(07^{\circ} 11^{\prime} \mathrm{S}, 39^{\circ} 44^{\prime} \mathrm{W}\right)$ in the state of Ceara. All of these municipalities are part of the Caatinga domain (Figure 1).

Each specimen was dissected by a longitudinal incision, and the respiratory, digestive and urinary tracts were removed and analyzed separately with the use of a stereomicroscope. The helminths were quantified, fixed in AFA, mounted on temporary slides in Hoyer medium (Everhart, 1957), and identified under a light microscope. Specimens of the parasites were deposited in the Parasitological Collection

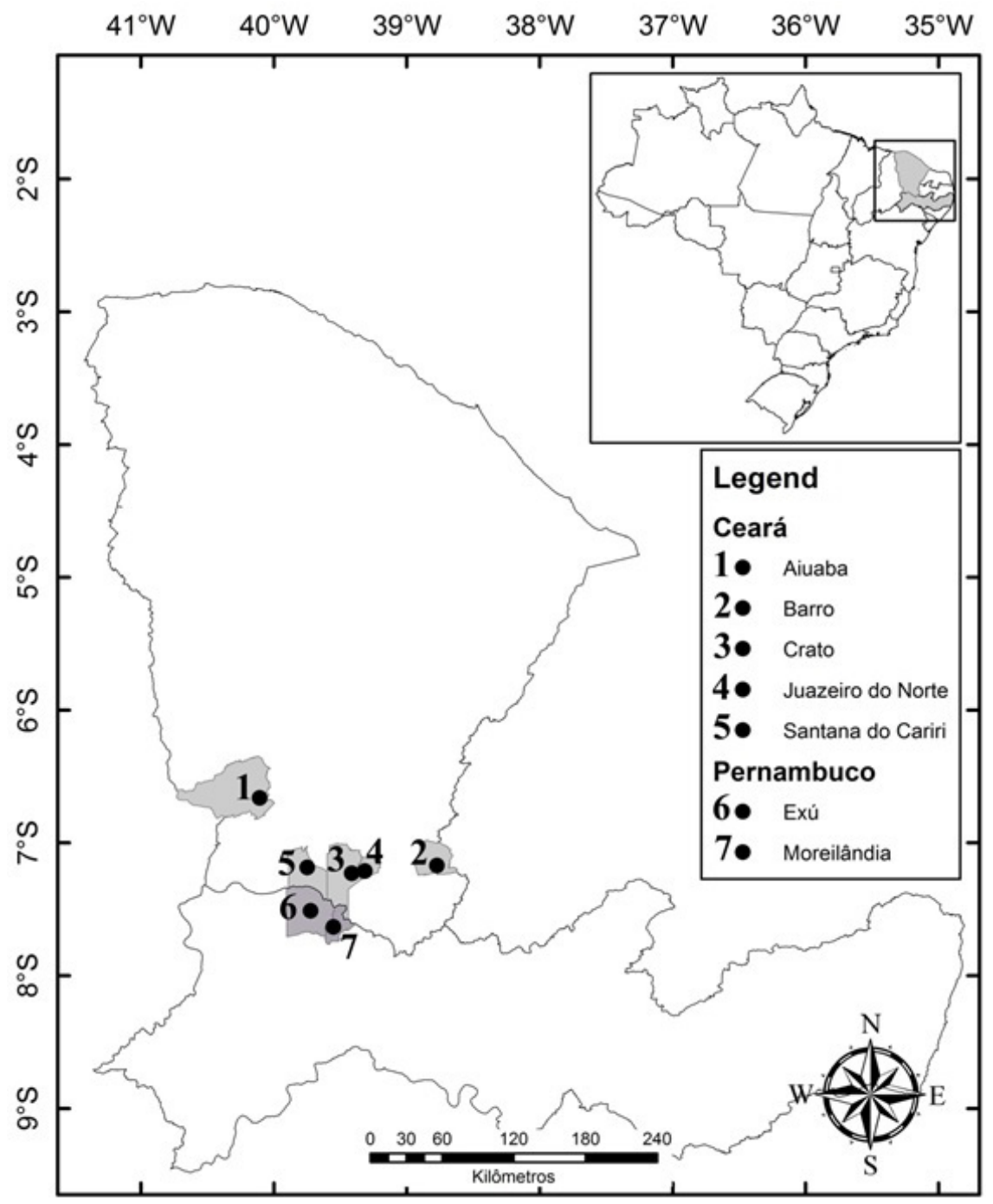

Figure 1. Site of collection of the Iguana iguana in semi-arid areas of northeastern from Brazil. 
of the Universidade Regional do Cariri - URCA-P (Numbers 423-443 URCA-P).

The helminths were identified according to Inglis et al. (1960), Vicente (1966) and Vicente et al. (1993).

The prevalence and mean intensity of infection was calculated according to Bush et al. (1997).

\section{Results}

The hosts were infected by Nematoda with prevalence was $66.6 \%(12 / 18)$, while in males, it was $75 \%(6 / 8)$ and in females, $60 \%(6 / 10)$. The intensity of infection overall was (15.02), while in males (6.6) and in females (8.4). Among nematodes found infecting I. iguana Pharingodonidae species were the most prevalent and with high mean intensity and Cosmocercidae larvae occurs with low prevalence (5\%) and high mean intensity (1.600). The others helminths occurs with prevalence among five and $11 \%$ and mean intensity ranging from 40 and 60 helminths/host. The Table 1 shows the nematodes and their respective parasitological indices and sites of infection.

Larvae of Pharyngodonidae and unidentified species of Alaeuris and Ozolaimus were found infecting the stomach and intestines of I. iguana. In this case, these nematodes were found in the larval and juvenile stages difficulting the identification at the species level.

\section{Discussion}

The species of Atractis Dujardin, has been reported infecting Testudinae (Salizar and Sanchez, 2007) and carnivorous lizards (Goldberg and Bursey, 2000; Ávila and
Silva, 2010) in South America. Atractis cruciata Linstow, 1902 has been registered infecting Tupinambis teguixin Linnaeus, 1758 and Stenocercus roseiventris Duméril \& Bibron, 1837 in Ecuador (Ávila and Silva, 2010).

Onchocercidae consist a nematode family composed for Macdonaldius Khana, 1933, Oswaldofilaria Travassos, 1933, Piratuba Lent and Freitas, 1921 and Piratuboides Bain and Sulahian, 1974 which infecting essentials carnivorous reptiles (Ávila and Silva, 2010).

Piratuba Lent and Freitas, 1921 is a group of seven species found in neotropical regions. Four species have been recorded in Brazil infecting lizards: Piratuba digiticauda Lent \& Freitas, 1941 infecting Plica umbra Linnaeus, 1758, Tropidurus torquatus Wied, 1820 and T. spinulosus (T. guarani) Alvarez, Cei and Scolaro, 1991; Piratuba laisoni Bain, 1974 infecting Polychrus marmoratus Linnaeus, 1758 and Anolis punctatus; Piratuba scaffi Bain, 1974 infecting Ameiva ameiva Linnaeus, 1758; Piratuba shawi Bain, 1974 infecting Kentropix calcarata Spix, 1825 (Vicente, 1981; Vicente et al, 1993; Ávila and Silva, 2010).

Physaloptera spp. infects various groups of vertebrates (Anderson, 2000), principally amphibians and reptiles throughout the Americas (Espinoza-Jiménez et al., 2007; Silva et al., 2008). In Brazil, unidentified species of Physaloptera have been recorded in the following species of lizards: Gekkonidae, Gymnophthalmidae, Hoplocercidae, Mabuyidae, Polychrotidae, Teiidae and Tropiduridae (Ávila and Silva, 2010). The specimens of Physaloptera we found were not identified to the species level due to the sample examined consisting only of individuals in the juvenile stages.

Table 1. Prevalence (\%), mean intensity and site of infection of gastrointestinal nematodes associated with Iguana iguana in semi-arid areas of northeastern from Brazil.

\begin{tabular}{|c|c|c|c|}
\hline Nematodes & Prevalence & Mean intensity & Site of infection \\
\hline \multicolumn{4}{|l|}{ Atractidae } \\
\hline Atractis sp. & 5 & 60 & large and small intestines \\
\hline \multicolumn{4}{|l|}{ Cosmocercidae } \\
\hline Cosmocercidae larvae & 5 & 1,600 & Stomach \\
\hline \multicolumn{4}{|l|}{ Onchocercidae } \\
\hline Piratuba sp. & 5 & 60 & large and small intestines \\
\hline \multicolumn{4}{|l|}{ Pharingodonidae } \\
\hline $\begin{array}{l}\text { Alaeuris vogelsangi Lent } \\
\text { \& Freitas, } 1948\end{array}$ & 77 & $2,343.07 \pm 1,047$ & large and small intestines \\
\hline $\begin{array}{l}\text { Alaeuris caudatus Lent \& } \\
\text { Freitas, } 1948\end{array}$ & 77 & $1,937.14 \pm 949.49$ & large and small intestines \\
\hline Alaeuris spp. & 72 & $607.14 \pm 521.04$ & large and small intestines \\
\hline $\begin{array}{l}\text { Ozolaimus megatyphlon } \\
\text { Rudolphi, } 1819\end{array}$ & 77 & $1,078.57 \pm 366.22$ & large and small intestines \\
\hline $\begin{array}{l}\text { Ozolaimus cirratus } \\
\text { Linstow, } 1906\end{array}$ & 77 & $764.28 \pm 233.22$ & large and small intestines \\
\hline Ozolaimus spp. & 66 & $691.66 \pm 162.13$ & large and small intestines \\
\hline \multicolumn{4}{|l|}{ Physalopteridae } \\
\hline Physaloptera sp. & 5 & 40 & Stomach \\
\hline \multicolumn{4}{|l|}{ Subuluridae } \\
\hline Subulura sp. & 11 & 55 & large and small intestines \\
\hline
\end{tabular}


Subulura Molin, 1860 commonly infects various species of birds and mammals (primates, rodents and marsupials) (Anderson, 2000). In Brazil, the first report of in reptiles was Subulura lacertilia Vicente, Van-Sluys, Fontes \& Kiefer, 2000 infecting Eurolophosaurus nanuzae Rodrigues, 1981 from Serra do Cipó, Minas Gerais and Cnemidophorus nativo Rocha, Bergallo \& Peccinini-Seale, 1997 from Guaratiba, resting areas, Bahia State (Ávila and Silva, 2010).

Alaeuris caudatus and Alaeuris vogelsangi are common parasites of I. iguana (Vicente et al., 1993). Alaeuris caudatus has been recorded infecting this lizard in Brazil, Peru, Venezuela and Puerto Rico (Vicente et al., 1993; Dyer et al., 1999; Ávila and Silva, 2010), but there has been no report of the parasitological indices for abundance these species. There have been reports of $A$. vogelsangi infecting iguanas in the following countries: Brazil (Petter, 1970; Ávila and Silva, 2013), Puerto Rico (Dyer et al., 1999) and Venezuela (Lent and Freitas, 1948). In the Caatinga areas from Ceará, Brazil, Lopes et al. (2007) noted prevalence 100\% (3/3) and mean intensity of infection $4,866.6 \pm 318,1$, and Ávila and Silva (2011) registered prevalence $40 \%(2 / 5)$ and mean intensity of infection 9,604.5 $\pm 5,424.2$ in Mato Grosso, Brazil. In Puerto Rico, Dyer et al. (1999) report prevalence $100 \%(1 / 1)$ and intensity of infection 27.

Ozolaimus cirratus and Ozolaimus megatyphlon infecting I. iguana from: Peru (Arrojo, 2002), Panama (Bursey et al., 2007), Colombia, Suriname and Brazil (Ávila and Silva, 2010). In Panama, Bursey et al. (2007) reported prevalence was $50 \%(1 / 2)$ and mean intensity of infection $792 \pm 880$ to $O$. cirratus. In, O. megatyphlon, the prevalence noted by Ávila and Silva (2011) in Mato Grosso, Brazil was 40\% $(2 / 5)$ and mean intensity $9,604.5 \pm 5,424.2$.

Parasitological indices found in the present study and in previous studies suggest that Alaeuris spp. and Ozolaimus spp. are commom species of Iguana iguana.

According to Roca et al. (2005), one of the characteristics of helminth component community for herbivorous reptiles is that they are not infected with helminths heteroxenous life cycles. However, recent studies have contradicted this assumption, as shown by the review studie by Ávila and Silva (2010) who recorded the presence of Cestoda and Trematoda infecting I. iguana (Ávila and Silva, 2011, 2010). As the findings of our study that found the presence of heteroxenous nematodes Physaloptera spp. and Subulura spp. infecting I. iguana. Therefore, we believe that new studies can clarify the community component of herbivorous lizards in the Neotropical region.

Moreover, we report here the first records of Atractis sp., Piratuba sp., Physaloptera sp. and Subulura sp. in the lizard, I. iguana.

\section{Acknowledgements}

We are grateful to the Conselho Nacional de Desenvolvimento Científico e Tecnológico - CNPq (PQ-311713/2012-2) for the research grant awarded to W.O.Almeida; to Coordenação de Aperfeiçoamento de Pessoal de Nível
Superior-CAPES for the scholarship awarded to D.A. Teles, A.A.M. Teixeira, V.F. Lima, A.M.A. Pereira; to Fundação Cearense de Apoio ao Desenvolvimento Científico e Tecnológico - FUNCAP for the scholarship awarded to S.V. Brito, J.A. Araujo-Filho; to R.W. Ávila, curator of Coleção Herpetológica da Universidade Regional do Cariri (URCA - H) for suggestions and revision taxonomic; we thank Proof-Reading-Service.com Ltda, for revision professional of English version of the manuscript. We also thank the valuable suggestions of the anonymous reviewer.

\section{References}

ANDERSON, R.C., 2000. Nematode parasites of vertebrates: their development and transmission. 2 nd ed. Wallingford: $\mathrm{CAB}$ International, pp. 17-34.

ARCE-NAZARIO, J.A. and CARLO, T.A., 2012. Iguana iguana invasion in Puerto Rico: facing the evidence. Biological invasion, vol. 14, no. 9, pp. 1981-1984.

ARROJO, L., 2002. Parasitos de animales silvestres en cautiverio en Lima, Peru. Revista Peruana de Biología, vol. 9, pp. 118-120.

ÁVILA, R.W. and SILVA, R.J., 2010. Check-list of helminths from lizards and amphisbaenians (Reptilia;Squamata) of South America. The Journal of Venomous Animals and Toxins Including Tropical Diseases, vol. 16, no. 4, pp. 543-572. http://dx.doi. org/10.1590/S1678-91992010000400005.

ÁVILA, R.W. and SILVA, R.J., 2011. Helminths of lizards (Reptilia:Squamata) from Mato Grosso State, Brazil. Comparative Parasitology, vol. 78, no. 1, pp. 129-139. http://dx.doi. org/10.1654/4473.1.

ÁVILA, R.W. and SILVA, R.J., 2013. Helminths of lizards from the municipality of Aripuanã in the Southern Amazon Region of Brazil. Journal of Helminthology, vol. 87, no. 1, pp. 12-16. http://dx.doi.org/10.1017/S0022149X11000769. PMid:22166366.

BREVES, P., PORTO, M., PISSINATTI, A., LUZ, D. and MENEZES, R.C., 2011. Helmintos oxyuridae parasitos Iguana iguana (Squamata, Lacertilia, Iguanidae) procedentes do Brasil. Arquivo Brasileiro de Medicina Veterinária e Zootecnia, vol. 63, no. 6, pp. 1574-1578. http://dx.doi.org/10.1590/S010209352011000600040 .

BURSEY, C.R., GOLDBERG, S.R. and TELFORD JUNIOR, J.R., 2007. Gastrointestinal helminths of 14 species of lizards from Panama with descriptions, of five new species. Comparative Parasitology, vol. 74, no. 1, pp. 575-583. http://dx.doi.org/10.1654/4228.1.

BUSH, A.O., LAFFERTY, K.D., LOTZ, J.M. and SHOSTAK, A.W., 1997. Parasitology meets ecology on its own terms: Margolis et al. revisited. The Journal of Parasitology, vol. 83, no. 4, pp. 575-583. http://dx.doi.org/10.2307/3284227.

CAMPOS, Z., 2004. Estudos dos iguanas do Pantanal. Embrapa Pantanal, vol. 1, no. 67, pp. 1-2.

CONNANT, R. and COLLINS, J.-T., 1998. A field guide: reptiles and amphibians of eastern \& central North America. 3rd ed. New York: Houghton Mifflin. 634 p.

DANTAS-TORRES, F., OLIVEIRA-FILHO, E.F., SOARES, F.A.M., SOUZA, B.O., VALENÇA, R.B.P. and SÁ, F.B., 2008. Ticks infesting amphibians and reptiles in Pernambuco, Northeastern Brazil. Revista Brasileira de Parasitologia Veterinária, vol. 17, no. 4, pp. 218-221. PMid:19265581. 
DYER, W.G., BUNKLEY-WILLIAMS, L. and ERNEST, H.W., 1999. Two new Caribbean records of parasitic nematodes colected from reptiles in Puerto Rico: Aplectana pusilla in Amphisbaena bakeri and Alaeuris vogelsangi in Iguana iguana. Caribbean Journal of Science, vol. 35, pp. 158-159.

ESPINOZA-JIMÉNEZ, A., GARCÍA-PRIETO, L., OSORIOSARABIA, D. and LEÓN-RÈGAGNON, V., 2007. Checklist of helminth parasites of the cane toad Bufo marinus (Anura: Bufonidae) from Mexico. The Journal of Parasitology, vol. 93, no. 4, pp. 937-944. http://dx.doi.org/10.1645/GE-1047R.1. PMid:17918380.

EVERHART, B.A., 1957. Notes on the helminths of Pseudemys scripta elegans Wied, 1838 in áreas of texas and Oklahoma. Biological Sciences, vol. 1, no. 1, pp. 38-43.

FREITAS, J.F.T. and LENT, H., 1937. Sobre Oswaldofilaria brevicaudata (Rhodian \& Vuylssteke, 1937) n. Comb. (Nematoda: Filaroidea). Memorias do Instituto Oswaldo Cruz, vol. 32, no. 3 , pp. 439-442. http://dx.doi.org/10.1590/S0074-02761937000300006.

GOLDBERG, S.R. and BURSEY, C.R., 2000. Transport of helminths to Havaii via the brown Anole, Anolis sagrei (Polycrhotidae). The Journal of Parasitology, vol. 86, no. 4, pp. 750-755. http:// dx.doi.org/10.1645/0022-3395(2000)086[0750:TOHTHV]2.0. CO;2. PMid:10958451.

INGLIS, W.G., DIAZ-UNGRIA, C. and COLES, W.J., 1960. Nematodes de Venezuela, IV: NEMATODES PARASITOS DE VERTEBRADOS VENEZOLANOS, II. Acta Biologica Venezuelica, vol. 3, pp. 1-24.

LARA-LÓPEZ, M.S. and GONZÁLEZ-ROMERO, A.G., 2002. Alimentación de La iguana verde Iguana iguana (Squamata:Iguanidae) en La Mancha, Vera Cruz, México. Acta Zoológica Mexicana, vol. 2, pp. 139-152. [nueva série].

LENT, H. and FREITAS, J.F.T., 1948. Uma coleção de nematódeos de vertebrados do museo de história natural de Montevideo. Memorias do Instituto Oswaldo Cruz, vol. 46, no. 1, pp. 1-71. http://dx.doi.org/10.1590/S0074-02761948000100001.

LOPES, S.G., SILVA, L.E.M., DANTAS, E.F., and ALMEIDA, W.O., 2007. Infecção por helmintos em três espécies de lagartos no nordeste brasileiro. Cadernos de Cultura e Ciência, vol. 1, no. 1 , pp. 47-51.

LÓPEZ-TORREZ, A.L., CLAUDIO-HERNANDEZ, H.J., RODRIGUEZ-GOMEZ, C.A., LONGO, A.V. and JOGLAR, R.L., 2012. Green Iguanas (Iguana iguana) in Puerto Rico: is it time for management? Biological Invasions, vol. 14, no. 1, pp. 35-45. http://dx.doi.org/10.1007/s10530-011-0057-0.

PASACHNIK, A.S., DE LEÓN, R.C., REYNOSO, V.H., RUPP, E., LEÓN, Y.M. and INCHAUSTEGUI, S.J., 2012. Green Iguanas:
Iguana iguana in the Dominican Republic. IRCF Reptiles \& Amphibians, vol. 19, pp. 132-134.

PETTER, A.J., 1970. Deux cas de poecilogynie chez les oxyuris parasites d' Iguana iguana. Bulletim of Museum Natural History of National Paris, vol. 41, pp. 1252-1260.

POWELL, R., HENDERSON, R.W., FARMER, M.C., BREUIL, A.C., ECHTERNACHT, G., VAN BUURT, C.M., ROMAGOSA, C.M. and PERRY, G., 2011. Introduced amphibians and reptiles in the greater Caribbean: patterns and conservation implications. In: A. HAYLEI, B.S. WILSON and J.Á. HORROCKS, eds. Conservation of caribbean island Herpetofaunas. Leiden: Brill, pp. 63-144. Conservation biology and the Wider Caribbean, vol. 1.

ROCA, V., CARRETERO, M.A., LLORENTE, G.A., MONTORI, A. and MARTIN, J.E., 2005. Helminth communities of two lizard populations (Lacertidae) from Canary Islands (Spain): Host diet-parasite relationships. Amphibia-Reptilia, vol. 26, no. 4, pp. 535-542. http://dx.doi.org/10.1163/156853805774806160.

SALIZAR, P. and SANCHEZ, L., 2007. Nuevos registros de nematodos en dos especies de tortugas (Reptilia: Testidines) en el Perú. Neotropical Helmintology, vol. 1, pp. 43-46.

SARMiENTO, L., TANTALEAN, M., and HUIZA, A., 1999. Nematodos parasites del hombre y de los animales en el Peru. Revista Peruana de Parasitologia, vol. 14, no. 1, pp. 9-65.

SILVA, A.S., ZANETTE, C.T., OLIVEIRA, C.B., SOARES, J.F., OTTO, M.A. and MONTEIRO, S.G., 2008. Parasitismo por Physaloptera sp., Kalicephalus sp. e Cryptosporidium sp. em lagarto (Tupinambis teguixin) no Rio Grande do Sul, Brasil. Revista Brasileira de Zoociências, vol. 10, pp. 269-272.

SMITH, T.H., GOLDEN, E., and MESHAKA, W.E.J.R., 2007. Populations density estimates for a green iguana (Iguana iguana) colony in a Florida State Park. Journal of Kansas Herpetology, vol. 21 , no. 21 , pp. 19-20.

VICENTE, J.J., 1966. Redescrição de Atractis cruciata Linstow, 1902, em novo hospedeiro (Nematoda, Atractidae). Atas da Sociedade Brasileira de Biologia., vol. 10, pp. 41-42.

VICENTE, J.J., 1981. Helmintos de Tropidurus (Lacertilia:Iguanidae) da Coleção Helmitológica do Instituto Oswaldo Cruz, II. Nematoda. Atas Soc. Biol., vol. 22, pp. 7-18.

VICENTE, J.J., RODRIGUES, H.O., GOMES, D.C. and PINTO, R.M., 1993. Nematóides do Brasil, parte III: nematoides de répteis. Revista Brasileira de Zoologia, vol. 10, no. 1, pp. 19-168. http:// dx.doi.org/10.1590/S0101-81751993000100003. 